ISSN = 1980-993X - doi:10.4136/1980-993X
www.agro.unitau.br/ambi-agua
E-mail: ambi-agua@agro.unitau.br
Tel.: (12) 3625-4116

\title{
Influence of additives on the retention of metal ions in a soil of Bangalore, India (doi:10.4136/ambi-agua.71)
}

\author{
Syed Abu Sayeed Mohammed ${ }^{1}$; Maya Naik²; Syed Tanveeruddin ${ }^{3}$ \\ ${ }^{1}$ Faculty of Civil Engineering, HKBK College of Engineering, \#22/1, Nagawara, \\ Bangalore 560045, India \\ E-mail: abubms@rediffmail.com \\ ${ }^{2}$ Faculty of Civil Engineering, BMS College of Engineering, \\ Bull Temple Road, Bangalore 560019, India \\ E-mail: snmcvbms@gmail.com \\ ${ }^{3}$ Alumni, Department of Medical Electronics, HKBK College of Engineering, \#22/1, Nagawara, \\ Bangalore 560045, India \\ E-mail: sy_tanveeruddin@yahoo.com
}

\begin{abstract}
Liners play an important role in minimizing migration of contaminants and are frequently constructed with natural materials serving as the primary barrier to contain chemicals and potentially harmful pollutants from municipal toxic waste leachates. To improve the performance of liners, additives like lime and cement at low percentages were added to Red Soil of Bangalore. Heavy metals like hexavalent chromium, copper and zinc and alkali metals like sodium and potassium were taken as contaminants. Batch leaching tests on 50 samples were performed according to ASTM D 3987 - 85 for soil and soil mixtures with contaminants. The heavy metals were potentiometrically monitored using ion selective mercury and platinum electrodes. The alkali metals were determined using a Flame Photometry. It has been observed that the retention of heavy metals elements followed the order copper $>$ zinc $>$ chromium over a period of 7 to 28 days. Chromium, zinc and copper attained equilibrium in this period as confirmed based on conductivity and $\mathrm{pH}$ data. Cement and lime had significant effect on copper and zinc. Specific adsorption of $\mathrm{Cu}$ onto $\mathrm{CaCO}_{3}$ surfaces may control $\mathrm{Cu}$ concentration in solution. $\mathrm{Zn}$ adsorption increases with $\mathrm{pH}$; Zinc hydrolysed at $\mathrm{pH}>7.7$ and these hydrolyzed species are strongly adsorbed to soil surfaces. $\mathrm{Cr}$ was retained only by $50 \%$ and additives did not have much effect as it is subjected to nonspecific adsorption (temporary). Cr was found to be highly mobile in alkaline soils. It was observed that the retention of alkali metals follows the order: $\mathrm{K}>\mathrm{Na}$. Cement and lime had positive effect on the retention of $\mathrm{Na}$ and $\mathrm{K}$. Sodium ion retarded immediately due to the removal of exchangeable cations, whereas potassium retarded more than sodium due to the lower hydrated radius of potassium. Scanning Electron Microscopy (SEM) characterization tests were performed to understand the soil mineral structure. Regular porous, sponge like, particles were detected in virgin soil containing crystals possibly of alumino sicilicate. Energy Dispersive Spectroscope (EDS) analysis indicated the presence of $\mathrm{Si}, \mathrm{Al}, \mathrm{Ca}, \mathrm{Ti}, \mathrm{Fe}, \mathrm{K}$, and $\mathrm{Na}$. These results indicate the possibility of using Red Soil as an adsorbent.
\end{abstract}

Keywords: Adsorption; liners; precipitation; leaching; electrodes; cation; ion exchange; landfill pollution. 


\section{Influência de aditivos na retenção de íons metálicos em um solo de Bangalore, Índia}

\section{RESUMO}

Camadas protetoras exercem um papel importante para minimizar a migração de contaminantes e, frequentemente, são construídas com materiais naturais que servem como barreira primária para contenção de substâncias químicas potencialmente poluentes e prejudiciais, resultantes da lixiviação de dejetos municipais tóxicos. Para melhorar o desempenho da camada protetora, calcário e cimento foram adicionados em baixas porcentagens em Solo Vermelho de Bangalore. Foram considerados contaminantes os metais pesados como cromo hexavalente, cobre e zinco, e também, metais alcalinos como sódio e potássio. Realizou-se uma bateria de testes de lixiviação em 50 amostras de acordo com o procedimento ASTM D 3987 - 85 recomendado para solos e misturas de solo com contaminantes. Os metais pesados foram potenciometricamente monitorados usando íons seletivos de mercúrio e eletrodos de platina. Os metais alcalinos foram analisados, usando-se um fotômetro de chamas. Foi observado que a retenção de metais pesados seguiu a ordem: cobre $>$ zinco $>$ cromo no período de 7 a 28 dias. O cromo, zinco e cobre atingiram equilíbrio nesse período, verificado com base nos dados de condutividade e $\mathrm{pH}$. Cimento e calcário tiveram efeito significativo para o cobre e zinco. Adsorção de $\mathrm{Cu}$ em superfícies de $\mathrm{CaCO}_{3}$ pode controlar a concentração de $\mathrm{Cu}$ em solução. Adsorção de $\mathrm{Zn}$ aumenta com o pH. O zinco foi hidrolisado em $\mathrm{pH}>7,7$ e esses elementos hidrolisados são fortemente adsorvidos nas superfícies dos solos. Só $50 \%$ do $\mathrm{Cr}$ foi retido, uma vez que o aditivo não teve muito efeito devido à adsorção não-específica (temporária). Verificou-se que o $\mathrm{Cr}$ é altamente móvel em solos alcalinos. Foi observado que a retenção de metais alcalinos seguiu a ordem $\mathrm{K}>\mathrm{Na}$. $\mathrm{O}$ cimento e o calcário tiveram efeito positivo na retenção de $\mathrm{Na}$ e $\mathrm{K}$. Íons de sódio foram retardados imediatamente devido à remoção de cátions trocáveis enquanto que os de potássio foram mais retardados do que os de sódio devido ao menor raio de hidratação do potássio. Foram realizadas análises com o microscópio de varredura eletrônica (SEM, sigla em inglês) para a caracterização da estrutura mineral dos solos. Partículas regulares e porosas, como esponjas, foram verificadas em solos virgens que continham cristais possivelmente de alumino-sicilicatos. Análises com espectroscópio de energia dispersiva (EDS, sigla em inglês) indicaram a presença de $\mathrm{Si}, \mathrm{Al}, \mathrm{Ca}, \mathrm{Ti}, \mathrm{Fe}, \mathrm{K}$, e $\mathrm{Na}$. Esses resultados indicam a possibilidade de se usar o Solo Vermelho como um adsorvente.

Palavras-chave: Adsorção; camadas de proteção; precipitação; lixiviação; eletrodos; cátion; troca iônica; poluição de aterros sanitários.

\section{INTRODUCTION}

Many cities in the developing countries are facing serious problem of disposing solid, liquid and hazardous waste generated by various sources. The large quantities of waste generated, which are disposed off on to the land, often pose a threat to ground water quality and has resulted in many incidents of ground water contamination.

Landfills have been the most economical and environmentally acceptable method for disposal of solid waste. However, the Leachate generated in landfills migrate downwards and poses threat to ground water, unless properly contained by a barrier system. Percolating fluid will tend to migrate downward through the landfill as Leachate. Unless properly regulated, leachate generated by precipitation and other liquids with in the waste flows from the landfill into underlying ground water. And thus, potentially, contaminate the drinking water aquifer. 
Liners play an important role in minimizing migration of contaminants. Liners are frequently constructed with natural materials serving as the primary barrier to contain chemicals and potentially harmful pollutants from municipal and toxic waste leachates. Geo technical liners are widely used for the control and containment of pollution. Hence the objective of any barrier system is to minimize the potential dangers associated with the migration of leachate generated, depending on the environmental requirements and the nature of the leachate itself. Liners may be designed for permanent containment, or temporary storage to allow for slow controlled migration of non-toxic leachate.

By comparing the literature, it has been found that Geosynthetic Clay Liners have more advantages (which give a hydraulic conductivity $\leq 1 \times 10^{-9} \mathrm{~cm} / \mathrm{s}$ ) than compacted clay liners (CCL), but their availability is limited. Soil liners possess many limitations but are widely used because of their universal availability, low cost, large attenuation capacity and their resistance to puncture and damage. In developing countries CCL's are more popular because of cheap labour and availability of good quality clays. Land fill engineering is sufficient to ensure a leachate retention time of 50 years (Mohammed, et al., 2006).

\subsection{Indian Scenario}

India has more than 285 million city dwellers even though the rate of urbanization is among the lowest in the world. The percentage of urban dwellers in India has been increasing from $10.8 \%$ in 1901 , to $17.3 \%$ in 1951 and to $25.7 \%$ in 1991 . Rural urban migration and high demographic natural increase in cities will further increase the proportion to more than 50 percent of the total population by 2020. A major concern is the safe disposal of solid waste generated by growing Indian cities. With advancements of new types of wastes added, particularly urban areas are affected the most as the volume of waste starts increasing, municipalities face severe problems in managing the wastes. Table 1 gives an indication of the waste generated by Indian cities per day (Naik and Mohammed, 2008).

Table 1. Solid Waste generation in major Indian cities in a day.

\begin{tabular}{clc}
\hline $\begin{array}{c}\text { Sample } \\
\mathbf{N}^{\mathbf{0}}\end{array}$ & \multicolumn{1}{c}{ City } & $\begin{array}{c}\text { Solid waste generated } \\
\text { per day in tonnes }\end{array}$ \\
\hline 1. & Delhi & 5922 \\
2. & Greater Mumbai & 5320 \\
3. & Chennai & 3036 \\
4. & Kolkatta & 2653 \\
5. & Hyderabad & 2187 \\
6. & Bangalore & 1669 \\
7. & Ahmedabad & 1302 \\
\hline
\end{tabular}

Scientifically designed sanitary land fills are a solution but for Indian conditions locally available soils can be used as liner materials but they have advantages and disadvantages, a number of studies on liners have already been done but emphasis was on determining strength and stability and also on chemical compatibility. The behaviour of CCL's to diffusion and transport phenomenon for major ions of leachates have been studied for Brown and Red Earth of Bangalore. Mathematical models have been used to model the migration of contaminants through soil liners. Different ions migrate through soil liners at different velocities depending on their diffusion coefficients (Naik and Sivapullaiah, 2003).

The behaviour of combination of materials has also been enumerated. Materials like Fly ash, Illite, Red Earth and mixture of fly ash and Bentonite, Illite and Bentonite by mixing lime has also been studied. 
It has been found that fly ash has high hydraulic conductivity, Illite possess reasonably high cation exchange capacity and specific surface area, the hydraulic conductivity is lower in chemical solutions than in water. Addition of $20 \%$ bentonite to Illite greatly enhances its quality as liner material. The compressibility of mixture is decreased and hydraulic conductivity lowered. The fly ash bentonite mixture is least compressible, possess good strength but its chemical compatibility is poor. It can be used to contain leachates containing heavy metal ions. Red Earth Bentonite mixture possesses many desirable properties for its potential use as a liner. Inclusion of bentonite has helped to increase the cation exchange capacity, it possess reasonably low compression index.

Non-plastic fly ash bentonite mixture becomes plastic on addition of lime. It slightly increases the compression index but lowers the hydraulic conductivity. Stabilization of Illite with Lime has improved its plasticity but slightly increased its hydraulic conductivity (Kantha and Sivapullaiah, 2000).

From the above work it can be concluded that the selection of barrier system should be site specific considering local hydrogeology, nature of waste, size of the landfill, climatic conditions, availability of suitable materials and economy. The phenomena of leaching (desorption) have not been given much thought on the soil of Bangalore. Transport parameters that can be used to predict transport of heavy metals are rarely reported in literature. Particularly hazardous waste might leach out from these liners and finally enter the ground water (Tanit et al., 2009).

\subsection{Behaviour of metals in soils}

Metals added to soil will normally be retained at the soil surface. Movement of metals into other environmental compartments, i.e., ground water, surface water, or the atmosphere, should be minimal as long as the retention capacity of the soil is not exceeded. The extent of movement of a metal in the soil system is intimately related to the solution and surface chemistry of the soil and to the specific properties of the metal and associated waste matrix. The retention mechanisms for metals added to soil include adsorption of the metal by the soil solid surfaces and precipitation. The retention of cationic metals by soil has been correlated with such soil properties as $\mathrm{pH}$, redox potential, surface area, cation exchange capacity, organic mater content, clay content, iron and manganese oxide content, and carbonate content. Anion retention has been correlated with $\mathrm{pH}$, iron and manganese oxide content, and redox potential.

In addition to soil properties, consideration must be given to the type of metal and its concentration and to the presence of competing ions, complexing ligands, and the $\mathrm{pH}$ and redox potential of the soil-waste matrix. Transport of metals associated with various wastes may be enhanced due to:

1) Facilitated transport caused by metal association with mobile colloidal size particles;

2) Formation of metal organic and inorganic complexes that do not sorb to soil solid surfaces;

3) Competition with other constituents of waste, both organic and inorganic, for sorption sites, and;

4) Decreased availability of surface sites caused by the presence of a complex waste matrix.

Because of the wide range of soil characteristics and various forms by which metals can be added to soil, evaluating the extent of metal retention by a soil is site/soil/waste specific. Changes in the soil environment over time, such as the degradation of the organic waste matrix, changes in $\mathrm{pH}$, redox potential, or soil solution composition, due to various 
remediation schemes or to natural weathering processes also may enhance metal mobility. The extent of vertical contamination is intimately related to the soil solution and surface chemistry of soil matrix with reference to the metal and waste matrix. It has been found that the relative mobility of nine metals through Montmorillinite and Kaolinite to be $\mathrm{Cr}(\mathrm{VI})>\mathrm{Se}$ $>\mathrm{As}(\mathrm{III})>\mathrm{As}(\mathrm{V})>\mathrm{Cd}>\mathrm{Zn}>\mathrm{Pb}>\mathrm{Cu}>\mathrm{Cr}(\mathrm{III})$ (Mc Lean and Bert, 1992).

The main aim of this work is to study the leaching behaviour of soil and soil mixtures to different chemical contaminants by conducting leaching tests. Scanning Electron Microscopy (SEM) characterization tests were performed for through understanding of soil mineral structure.

\section{MATERIALS AND METHODS}

Red Soil of Bangalore drawn from the Campus of Indian Institute of Science (IISc), Bangalore is taken as the main soil; IISc was selected as it is a big campus with minimal contamination. Additives to enhance its properties selected were Lime and Cement. A known percentage by weight of an inorganic contaminant is mixed with soil or soil mixture and allowed to dry naturally for 7 days and also extended to cure for 28 days. Some of the contaminants introduced are sodium, potassium, copper, zinc, and chromium. The standard procedures followed were the ASTM (American Standard Testing Methods) D3987 - 85 (Reapproved 2004). A load ratio of $100 \mathrm{mg} / \mathrm{kg}$ and $50 \mathrm{mg} / \mathrm{kg}$ was maintained (1000 $\mathrm{ml}$ of 100 ppm contaminant solution was added to $1 \mathrm{~kg}$ of soil to give a load ratio of $100 \mathrm{mg} / \mathrm{kg}$ ).

Batch leaching test was done by taking a known weight of dried mixture and mixing it in a known volume of distilled water maintaining a solid to liquid $(\mathrm{S} / \mathrm{L})$ ratio of 1:20, and subjecting it to shaking for a period of 18 hours in a sample shaker at a speed of 30 RPM. The leached solution is taken and after centrifuging and filtering, the sample was sent for chemical analysis, the amount of contaminant leached was determined (ASTM, 2004).

A cost effective method has been used to determine concentrations of copper, zinc and chromium by Potentiometry. For the determination of copper and zinc, mercury electrode with Calomel as reference electrode was used. First standardization of this method was done using standard samples of $10,20,50,100 \mathrm{mg} / 1$ of contaminants prepared and determined potentiometrically and standard graphs were obtained (Jeffery et al., 1997).

\subsection{Apparatus: Mercury Electrode}

The electrode is a $U$ tube easily constructed with pyrex tubing. The platinum wire dipping into the mercury welded to a copper wire. The mercury must be pure and clean, in case of doubt, the mercury should be washed with dilute nitric acid and then thoroughly rinsed with distilled water. The electrode is filled with mercury so that the wide portion is half full. It is most important that no mercury is spilled into the titration vessel during the titration. After each titration the electrode is repeatedly washed with distilled water as shown in Figures 1, 2 and 3.

\subsection{Titration Assembly}

The electrode system consists of a mercury electrode and a saturated Calomel reference electrode, both supported in a $250 \mathrm{ml}$ pyrex beaker. Provision is made for magnetic stirring and the potential is followed by means of an electronic milli voltmeter.

\subsection{Reagents required}

Standard EDTA solution of 0.05 M, Mercury EDTA Solution (Mixequal volumes of 0.05 M Mercury Nitrate and 0.05 M EDTA, neutralize the liberated acid by addition of a few drops of $3 \mathrm{M}$ ammonia solution, dilute $10 \mathrm{ml}$ of this solution to $100 \mathrm{ml}$ with distilled water). 
Acetate buffer solution: - mix equal volumes of $0.5 \mathrm{M}$ sodium acetate solution and $0.5 \mathrm{M}$ acetic acid solution. The resulting solution has a $\mathrm{pH}$ of about 4.7 .

\subsection{Procedure}

The general procedure is as follows: place $25 \mathrm{ml}$ of the metal ion solution in a $250 \mathrm{ml}$ pyrex beaker, add $25 \mathrm{ml}$ of the acetate buffer solution and one drop of Mercury EDTA solution. Use the titration assembly described above, stir magnetically. Titrate potentiometrically with a standard $0.05 \mathrm{M}$ EDTA solution added to $0.1 \mathrm{ml}$ or less as soon as the potential begins to rise, wait for a steady potential to be established after each addition. Soon after the end point the change of potential with each addition of EDTA becomes smaller and only a few large additions need be made.

Plot the titration curve (potentiometrically in millivolts against volume of standard EDTA solution) and evaluate the end point. In general, results accurate to better than 0.1 percent are obtained (Jeffery et al., 1997).

\subsection{Determination of chromium}

The chromium in the substance is converted into chromate or dichromate by any of the usual methods. A platinum indicator electrode and a saturated Calomel electrode are used. Place a known volume of the dichromate solution in the titration beaker and add $10 \mathrm{ml}$ of 10 percent sulphuric or hydrochloric acid per $100 \mathrm{ml}$ of final volume of the solution and also 2.5 $\mathrm{ml}$ of phosphorus acid. Insert electrodes stir and after adding $1 \mathrm{ml}$ of a standard ammonium iron sulphate solution the emf is measured continue to add the iron solution reading the emf after each addition then plot the titration curve and determine the end point (Jeffery et al., 1997).

\subsection{Flame photometric estimation of sodium and potassium}

Transfer 2, 4, 6, 8 and $10 \mathrm{~cm}^{3}$ of standard $\mathrm{NaCl}$ or $\mathrm{KCl}$ solution into different $50 \mathrm{~cm}^{3}$ volumetric flasks. Make up all the solutions upto the mark with distilled water and shake well for uniform concentration. Switch on the flame photometer and light the gas at the burner. Regulate the flow of gas and air supply. Now dip the capillary tube into the beaker containing distilled water and adjust the reading to zero. Now feed the $100 \mathrm{ppm} \mathrm{NaCl} / \mathrm{KCl}$ solution and adjust the reading to hundred. Feed the $\mathrm{NaCl} / \mathrm{KCl}$ solutions prepared through the capillary tube one by one including the solution of unknown volume, and note down the intensity (flame photometer reading) for each. Plot a graph of intensity against the volume of $\mathrm{NaCl} /$ $\mathrm{KCl}$ and find the unknown volume and calculate amount of sodium / potassium in it (Jeffery et al., 1997).

\subsection{Preparation of leached samples for SEM analysis}

$\mathrm{A} \mathrm{L} / \mathrm{s}$ ratio of 20 was maintained and samples of mixtures spiked with contaminants were taken and subjected to leaching tests according to ASTM D3987- 85 for 18 hours, with a buffer period of another 8 hours. The extraction time was kept at about 24 hours. The extract was filtered through Whatman $n^{\circ} .45$ filter paper to separate soil from fluid. The filter paper was rinsed with distilled water and the resulting soil solution was transferred into a porcelain dish and covered to avoid contamination and allowed to dry naturally. The dried soil extract was sent for SEM and EDS analysis. One sample of virgin soil was also sent to develop a comparison (Ali Baig and Sivapullaiah, 2008). 


\subsection{Preparation of moulds for Scattering Electron Microscopy (SEM) and Energy Dispersive Spectroscope (EDS)}

The specimen is mounted in this fashion: first there is a metal stub on top of which double sided carbon tape is used and sample is stuck on this carbon tape; later this entire stub is placed in the coating machine for the metal coating process. For an electrically conductive specimen, observation of the specimen without metal coating is the best method. For a nonconductive specimen, however, metal coating is usually applied to give the specimen electrical conductivity. This decreases the specimen's capacity to acquire an electrostatic charge and increases the yield of secondary electrons. The important thing to remember when applying a metal coating is that the coat of metal film must be as thin as possible so that the specimen surface morphology is not completely covered by coating.

The resultant images reveal remarkable structural resolution down to a few nanometers with great accuracy because the film provides a continuous coating over all the sample contours. In our case platinum was used with coating time of 120 seconds and vacuum less than 5 Pascal, as soil is a non magnetic material.

The mould or stub is kept in the vacuum chamber and SEM imaging and EDS is done, SEM and EDS was taken through JEOL JSM 6360 - A Model with a magnification capacity of X500, X1000, X2000 and accelerating voltage of $20 \mathrm{KV}$ with working distance (WD) 10 $\mathrm{mm}$ with a Spot size 58. First area of image is chosen and focused then via software EDS. Analysis is done on the same image by either selecting spot analysis or line analysis or area analysis. In our case area analysis was done and after the x-ray scan is complete the EDS result is also obtained simultaneously both qualitative and quantitatively (Jeol, 2008).

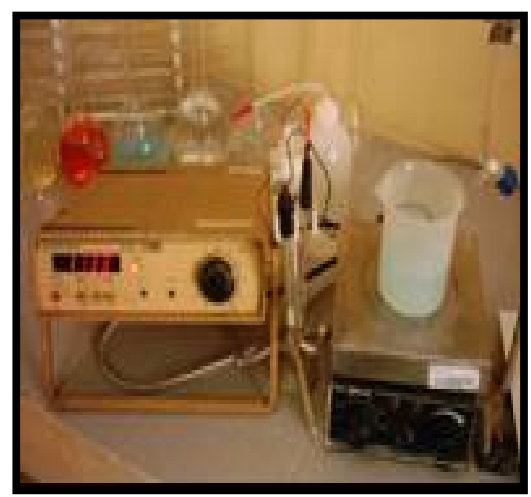

Figure 1. A set up for the potentiometric determination of copper using mercury electrode.

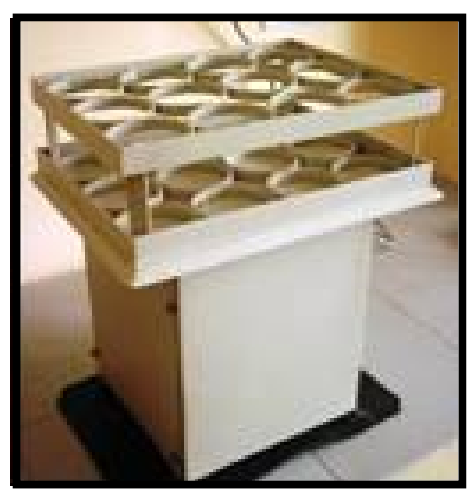

Figure 2. Sample shaker fabricated by the authors.

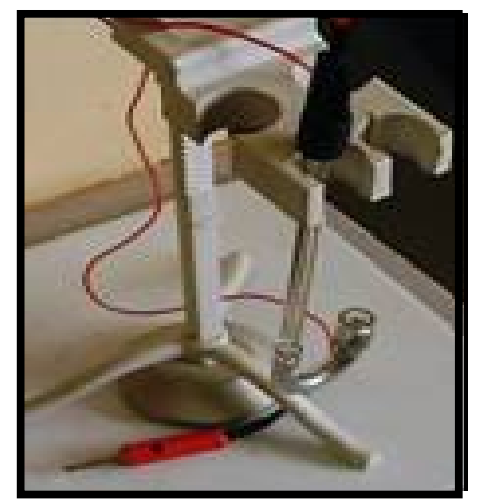

Figure 3. Close up of mercury electrode specially fabricated for this work.

\section{RESULTS AND DISCUSSION}

The results of all the tests conducted on samples have been shown in Tables 2, 3, 4, 5 and also graphs have been plotted as shown in Figures 9 and 10.

\subsection{Chromium}

In the present study the initial results obtained with different materials are not encouraging, only soil with $6 \%$ lime showed some adsorption but over 28 days period it has been desorbed suggesting nonspecific (temporary) adsorption. As observed from the graph, the leachability of $\mathrm{Cr}^{6+}$ is highest in almost all the combinations studied; indicating $\mathrm{Cr}$ is not sorbed by the given soil.

The present study highlights that only soil with $6 \%$ lime showed some adsorption but over 28 days period it has been desorbed suggesting nonspecific adsorption. 
Hexavalent chromium was found to be highly mobile in alkaline soils, and hence other properties such as Cation Exchange Capacity, surface area and percent clay content have no significant influence on the mobility of $\mathrm{Cr}$ (VI). And hence $\mathrm{Cr}$ (VI) is not retained in Red soil treated with lime and cement. The reduction reaction in the presence of organic matter proceeds at a slow rate at environmental $\mathrm{pH}$ and temperatures.

It may be due to redox reactions that occur at extremely slow rate requiring more time which is $\mathrm{pH}$ dependent. Irrespective of adsorbent chromium (VI) adsorption increases with decrease in $\mathrm{pH}$. Cations like $\mathrm{K}^{+}, \mathrm{Ca}^{2+}, \mathrm{Mg}^{2+}$ can compete with hexavalent chromium and slightly influence the $\mathrm{Cr}$ (VI) adsorption.

Conductivity data suggests that it varies from 0.7 to 1.50 millisiemens after seven days and after reaching 28 days it varied from 1.90 to 3.20 because hexavalent chromium is highly mobile in soils due to addition of excess lime.

Chromium exists in two possible oxidation states in soils: the trivalent chromium, $\mathrm{Cr}$ (III) and the hexavalent chromium, $\mathrm{Cr}(\mathrm{VI})$. Forms of $\mathrm{Cr}(\mathrm{VI})$ in soils are as chromate ion, $\mathrm{HCrO}^{4}$ predominant at $\mathrm{pH}<6.5$, or $\mathrm{CrO}_{4}{ }^{2-}$ predominant at $\mathrm{pH} 6.5$, and as dichromate, $\mathrm{Cr}_{2} \mathrm{O}_{7}{ }^{2-}$ predominant at higher concentrations $(>10 \mathrm{mM})$ and at $\mathrm{pH} 2-6$. The dichromate ions pose a greater health hazard than chromate ions. Both $\mathrm{Cr}(\mathrm{VI})$ ions are more toxic than $\mathrm{Cr}(\mathrm{III})$ ions.

Because of the anionic nature of $\mathrm{Cr}(\mathrm{VI})$, its association with soil surfaces is limited to positively charged exchange sites, the number of which decreases with increasing soil $\mathrm{pH}$. Iron and aluminum oxide surfaces will adsorb $\mathrm{CrO}_{4}{ }^{2-}$ at acidic and neutral $\mathrm{pH}$. It was concluded that the adsorption of $\mathrm{Cr}(\mathrm{VI})$ by ground-water alluvium was due to the iron oxides and hydroxides coating the alluvial particles. The adsorbed $\mathrm{Cr}(\mathrm{VI})$ was, however, easily desorbed with the input of uncontaminated ground water, indicating nonspecific adsorption of $\mathrm{Cr}(\mathrm{VI})$. The presence of chloride and nitrate had little effect on $\mathrm{Cr}(\mathrm{VI})$ adsorption, whereas sulfate and phosphate inhibited adsorption. It has been found that $\mathrm{SO}_{4}{ }^{2-}$ and dissolved inorganic carbon inhibited $\mathrm{Cr}(\mathrm{VI})$ adsorption by amorphous iron oxyhydroxide and subsurface soils (Grove and Ellis, 1980).

The presence of sulfate, however, enhanced $\mathrm{Cr}(\mathrm{VI})$ adsorption to kaolinite and $\mathrm{BaCrO}_{4}$ may form in soils at chromium contaminated waste sites. No other precipitates of hexavalent compounds of chromium have been observed in a $\mathrm{pH}$ range of 1.0 to 9.0. Hexavalent chromium is highly mobile in soils. In a study of the relative mobilities of 11 different trace metals for a wide range of soils. It was found that clay soil, containing free iron and manganese oxides, significantly retarded $\mathrm{Cr}(\mathrm{VI})$ migration.

Hexavalent chromium was found to be the only metal studied that was highly mobile in alkaline soils. The parameters that correlated with $\mathrm{Cr}(\mathrm{VI})$ immobilization in the soils were free iron oxides, total manganese, and soil $\mathrm{pH}$, whereas the soil properties, cation exchange capacity, surface area, and percent clay had no significant influence on $\mathrm{Cr}(\mathrm{VI})$ mobility. It has been reported that $\mathrm{Cr}(\mathrm{III})$ forms hydroxy complexes in natural water, including $\mathrm{Cr}(\mathrm{OH})_{2}{ }^{+}$, $\mathrm{Cr}(\mathrm{OH})^{2+}, \mathrm{Cr}(\mathrm{OH})_{3}{ }^{0}$ and $\mathrm{Cr}(\mathrm{OH})_{4}{ }^{-}$. Trivalent chromium is readily adsorbed by soils. In a study of the relative mobility of metals in soils at $\mathrm{pH} 5, \mathrm{Cr}$ (III) was found to be the least mobile. Hydroxy species of $\mathrm{Cr}$ (III) precipitate at $\mathrm{pH} 4.5$ and complete precipitation of the hydroxy species occurs at $\mathrm{pH}$ 5.5. Hexavalent chromium can be reduced to $\mathrm{Cr}$ (III) under normal soil $\mathrm{pH}$ and redox conditions. Soil organic matter has been identified as the electron donor in this reaction. The reduction reaction in the presence of organic matter proceeds at a slow rate at environmental $\mathrm{pH}$ and temperatures. It has been reported that in natural soils the reduction reaction may be extremely slow, requiring years. The rate of this reduction reaction, however, increases with decreasing soil $\mathrm{pH}$. Soil organic matter is probably the principal reducing agent in surface soils. In subsurface soils, where organic matter occurs in low concentration, $\mathrm{Fe}(\mathrm{II})$ containing minerals reduce $\mathrm{Cr}(\mathrm{VI})$ however it was observed that this reaction only occurred in the subsurface soil with a $\mathrm{pH}<5$. The reduction of $\mathrm{Cr}(\mathrm{VI})$ occurred 
in all four subsurface soils tested by decreasing the $\mathrm{pH}$ to 2.5 . However, it has been demonstrated that under conditions prevalent in some soils, $\mathrm{Cr}$ (III) can be oxidized. In the presence of oxidized $\mathrm{Mn}$, which serves as an electron acceptor, was determined as an important factor in this reaction. Industrial use of chromium also includes organic complexed $\mathrm{Cr}(\mathrm{III})$. Chromium (III) complexed with soluble organic ligands will remain in the soil solution. In addition to decreased $\mathrm{Cr}$ (III) adsorption, added organic matter also may facilitate oxidation of $\mathrm{Cr}$ (III) to $\mathrm{Cr}(\mathrm{VI})$ (Mc Lean and Bert, 1992).

Even $\mathrm{pH}$ and conductivity data suggest that there is lot of activity taking place which suggests that it is one of the metal ion with the highest mobility.There has been adsorption of over 50\% compared to zinc and copper, and this being the lowest in agreement with Mc Lean and Bert. (1992).

\subsection{Copper}

It has been found that copper reaches equilibrium in a short period and there is not much change with time. It is observed from the graph that copper leachability is about $10-12 \%$, lime has been found to have good attenuation effect on copper. However, copper has high affinity for soluble organic ligands and the formation of complexes may greatly increase its mobility in soils. The present study supports the fact that copper is retained in soils through exchange and specific adsorption mechanisms. Particularly in alkaline mixtures specific adsorption of copper onto $\mathrm{CaCO}_{3}$ is likely to take place and cement has moderate effect probably due to very low concentration of cement used. Variation of $\mathrm{pH}$ with time for different combinations of soil mixures with copper. It is observed that $\mathrm{pH}$ varies from 4.86 to 8.12 with the addition of lime which contributes hydroxyl ions (Lo and Lin, 2009).

At concentrations typically found in native soils, $\mathrm{Cu}$ precipitates are unstable. This may not be the case in waste-soil systems and precipitation may be an important mechanism of retention. It has been suggested that a clay mineral exchange phase may serve as a sink for $\mathrm{Cu}$ in noncalcareous soils. It has been found that copper reaches equilibrium in a short period; there is not much change over time (McBride and Bouldin, 1984).

\subsection{Zinc}

Zinc is readily adsorbed by clay minerals, carbonates, or hydrous oxides. It has been found that the greatest percent of the total $\mathrm{Zn}$ in polluted soils and sediments was associated with $\mathrm{Fe}$ and $\mathrm{Mn}$ oxides. Precipitation may become a more important mechanism of $\mathrm{Zn}$ retention in soil-waste systems. As with all cationic metals, $\mathrm{Zn}$ adsorption increases with $\mathrm{pH}$. Zinc hydrolysed at $\mathrm{pH}>7.7$ and these hydrolyzed species are strongly adsorbed to soil surfaces. Zinc forms complexes with inorganic and organic ligands that will affect its adsorption reactions with the soil surface. It has been found that Zinc reaches equilibrium over a period of 144 hours there is not much change over time. Lime and cement have been found to retain zinc more than only soil (Kurdi and Doner, 1983).

It has been found that zinc reaches equilibrium within 28 days and there is not much change with time. Lime and cement have been found to retain zinc more than any soil.

As observed from the graph, zinc is readily adsorbed by the present Red Soil and precipitation may become a more important mechanism of $\mathrm{Zn}$ retention in soil-waste systems. It is observed that conductivity varies from 0.90 to 2.2 millisiemens which is mainly due to addition of lime which contributes many ions to soil solution.(Lo and Lin, 2009).

In soil lime system the $\mathrm{pH}$ of the system increases immediately. Due to this, there is a possibility of formation of $\mathrm{ZnOH}^{+}$species and also to some extent precipitation of zinc onto the surface of the soil. The $\mathrm{ZnOH}^{+}$species gets adsorbed onto the soil surface along with zinc 
ions, in addition to zinc retention through ion exchange and adsorption mechanism. This leads to an increase in the total capacity of soil to retain more zinc (Rajasekhar et al., 1995).

The $\mathrm{pH}$ at the surface of the particle is 0.5 to 1 unit higher than the ambient $\mathrm{pH}$. Hence the precipitation of the metal ions can still occur onto the surfaces of the material at $\mathrm{pH}$ values 0.5 to 1.0 unit lower than the $\mathrm{pH}$ at which solution precipitation occurs. For only soil, since Red Soil is acidic with a $\mathrm{pH}$ of 4 at low $\mathrm{pH}$ conditions the concentration of the $\mathrm{H}^{+}$ions is high, hence these $\mathrm{H}^{+}$ions are also competing with zinc ions for the available exchangeable positions as well as adsorption sites leading to low retention of zinc ions at low $\mathrm{pH}$ conditions (Kantha et al., 2003). It is observed that $\mathrm{Zn}$ adsorption increases with $\mathrm{pH}$ in soil-lime system and reaches equilibrium condition. There is a possibility of formation of $\mathrm{ZnOH}^{+}$and the hydrolysed species are strongly adsorbed to soil surfaces.

\subsection{Sodium and potassium}

By comparing the experimental data it has been found that potassium is being adsorbed more than sodium. Over a period of time the sorption of potassium is getting stronger where as desorption of sodium has occurred. Lime and cement as additives to soil have proved to enhance its retention capacity. The $\mathrm{pH}$ for sodium varied between 7.75 to 12.83 and conductivity between 0.7 to 2.8 after 7 days and after 28 days it varied from 7.83 to 8.96 and conductivity from 1 to 1.0 millisiemens. The $\mathrm{pH}$ for Potassium varied between 7.2 to 13.03 and conductivity from 0.6 to 2 after 7 days and after 28 days $\mathrm{pH}$ varied from 7.2 to 8.3 and conductivity from 0.7 to 1.4 millisiemens.

The surface of an individual clay particle or organic colloid is negatively charged. As a consequence their surfaces attract and adsorb positively charged ions called cations. When water is added to soil, cations can move into solution; however they are still attracted to the clay particle or surface and as a result swarm around them. The mechanism of adsorption and desorption is important even though less than $1 \%$ of cations will do this at any one time. This is because detached cations become available to plants. Positively charged ions capable of being readily substituted from soil solution and onto the surface of a negatively charged soil particle and vice a versa are termed as exchangeable cations. The exchangeable cations of most importance are $\mathrm{Ca}^{2+}, \mathrm{Mg}^{2+}, \mathrm{K}^{+}, \mathrm{Na}^{+}, \mathrm{H}^{+}, \mathrm{Al}^{3+}$. In order to become available to a plant, a cation adsorbed on a soil particle must be replaced by a cation present in the soil solution. Plant roots facilitate this process by excreting a hydrogen ion into soil solution in order to exchange this for a cation (e.g. potassium).

The process of substitution is known as cation exchange and occurs when a cation in the soil solution moves into the hemisphere of a cation located on the surface of a negatively charged particle. Cation exchange is therefore defined as the interchange between a cation on the surface of any negatively charged particle and the soil solution. Whilst the cation themselves are still attracted to the clay particle the force of attraction on the cations diminishes rapidly with increasing distance from the negatively charged surface. This phenomenon of attracted cations and negatively charged particles is known as diffuse double layer. Literally it is a double layer because there are two layers of charge (i.e. negative and positive) and diffuser because the outer layer of cations is not well defined. The force of attraction between the negatively charged particles and the cations reduces quickly with increasing distance.

The more strongly attracted a cation is to their exchange surface the greater is the chance of adsorption. This is known as energy of adsorption. The energy of adsorption of a cation is a function of the valence. This is the reason why trivalent cations such as aluminium and divalent cations such as calcium and magnesium have energy of adsorption almost three and two times that of monovalent cations such as potassium and sodium. As a consequence exchangeable cations of aluminium, calcium or magnesium stay close to the soil particle and 
do not interfere with the cohesion between aggregated particles. In fact, these cations initiate the process of particle aggregation in soil.

The valence of an exchangeable cation therefore determines the double layer thickness. Higher the valence of the dominant exchangeable cation, the thinner is the double layer. However, differences in the thickness of the double layer can still occur even when the cations are of equivalent charge or valency.

When the valence of the cation is equal the cation with the smallest hydrated radius is more strongly adsorbed. In case of the monovalent cations of potassium and sodium, the potassium ion is more strongly adsorbed since it has a smaller hydrated radius, hence is more strongly adsorbed to the site of negative charge in comparison to sodium ion, is loosely held and so ready to hydrate and sodium rich soil will disperse. (The hydrated radius of potassium is 0.330 nanometer and for sodium it is 0.360 nanometer).

This phenomenon was observed while mixing sodium into soil; it turned into slurry where as the same quantity of potassium made the soil hard and workability started reducing.

The charge of the cation and the size of the hydrated cation essentially govern the preferences of cation exchange equilibria. In summary, highly charged cations tend to be held more tightly than cations with less charge and secondly cations with a small hydrated radius are bound more tightly and are less likely to be removed from the exchange complex. The combined influence of these can be summarized by the lysotropic series $\mathrm{Al}^{3+}>\mathrm{Ca}^{2+}>\mathrm{Mg}^{2+}>$ $\mathrm{K}^{+}>\mathrm{Na}^{+}>\mathrm{H}^{+}$. (University of New South Wales, 2007).

\subsection{SEM and EDS analysis}

Scattering Electron Microscopy (SEM) characterization tests were performed for thorough understanding of soil mineral structure, the observations reveal at higher size range regular porous sponge like large particles were detected from virgin soil sample.

In the regular porous sponge like particles crystals seem to be of alumino silicate can be seen. This is widely used as an adsorbent for removal of metals. The main crystalline material of zeolite is alumino silicate indicating possibility of using Red Soil as an adsorbent for removing metal ions (Figures 4, 5, 6, 7 and 8).

SEM observations of samples spiked with sodium, potassium, zinc and copper show aggregation and formation of homogenous mass from regular sponge like particles of virgin soil, which shows sorption has taken place. Energy Dispersive Spectroscope (EDS) analysis indicates presence of elements like $\mathrm{Si}, \mathrm{Al}, \mathrm{Ca}, \mathrm{Ti}, \mathrm{Fe}, \mathrm{k}, \mathrm{Na}$. This is in accordance with the conductivity data obtained experimentally (Young and Young, 2003).

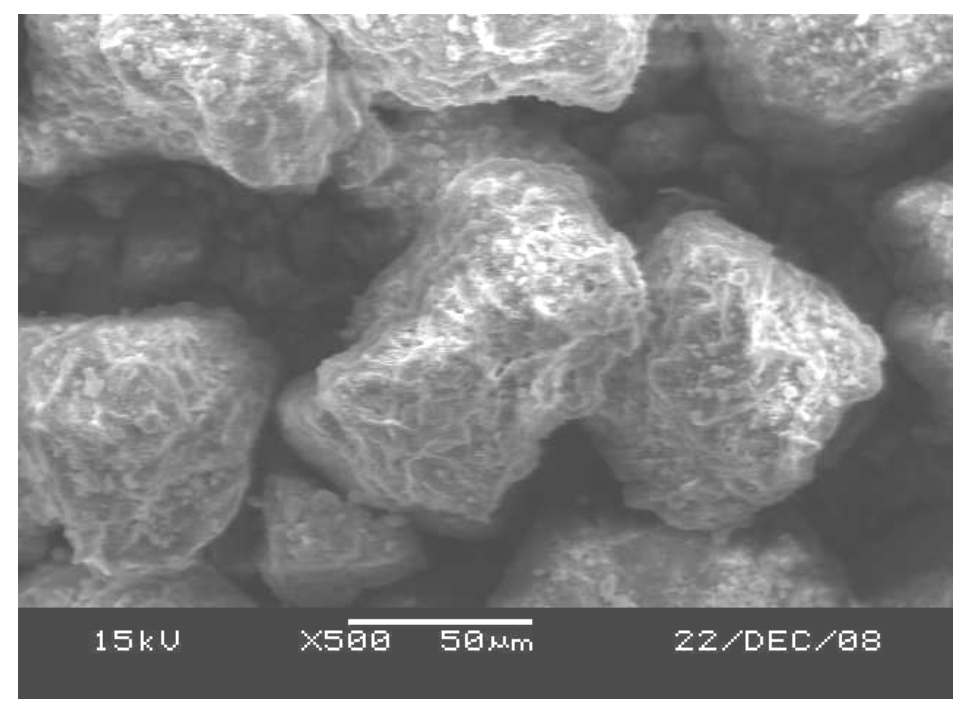

Figure 4. Virgin Soil. 
MOHAMMED, S. A. S.; NAIK, M.; TANVEERUDDIN, S. Influence of additives on the retention of metal ions in a soil of Bangalore, India. Ambi-Agua, Taubaté, v. 4, n. 1, p. 20-36, 2009. (doi:10.4136/ambi-agua.71)

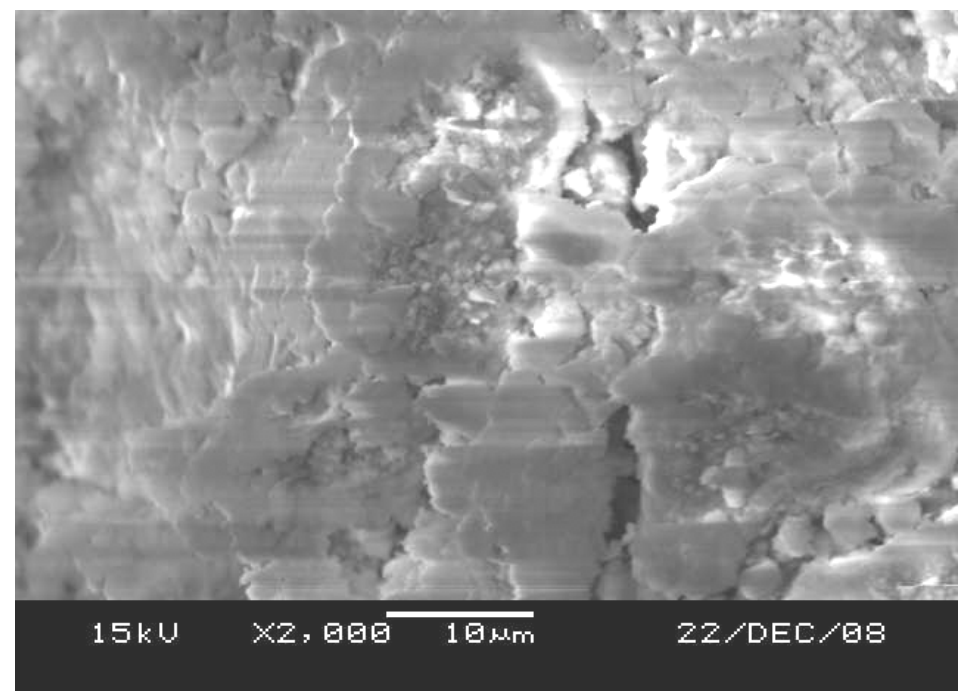

Figure 5. Soil $+6 \%$ Lime $+100 \mathrm{mg} / \mathrm{kg} \mathrm{K}$.

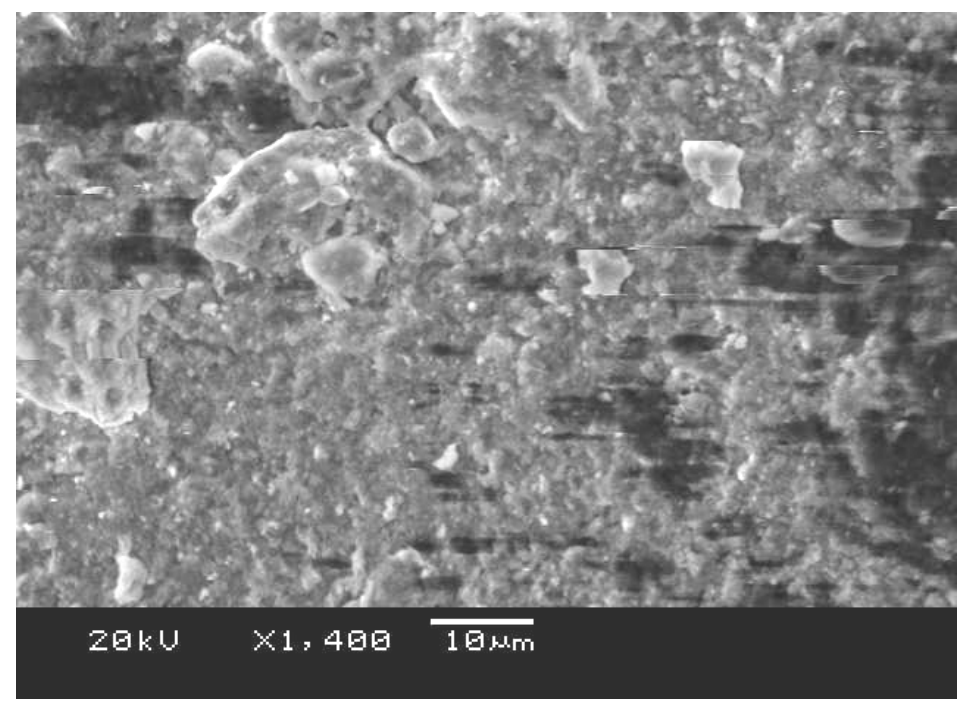

Figure 6. Soil $+1 \%$ Cement $+100 \mathrm{mg} / \mathrm{kg} \mathrm{Na}$.

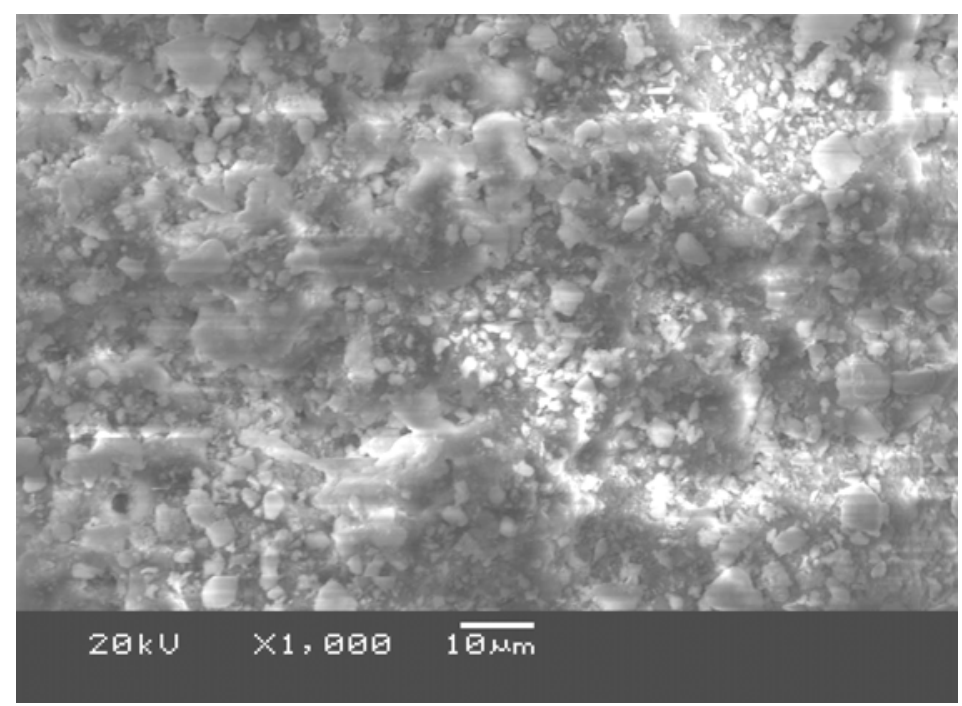

Figure 7. Soil $+3 \%$ Lime $+100 \mathrm{mg} / \mathrm{kg} \mathrm{Zn}$. 


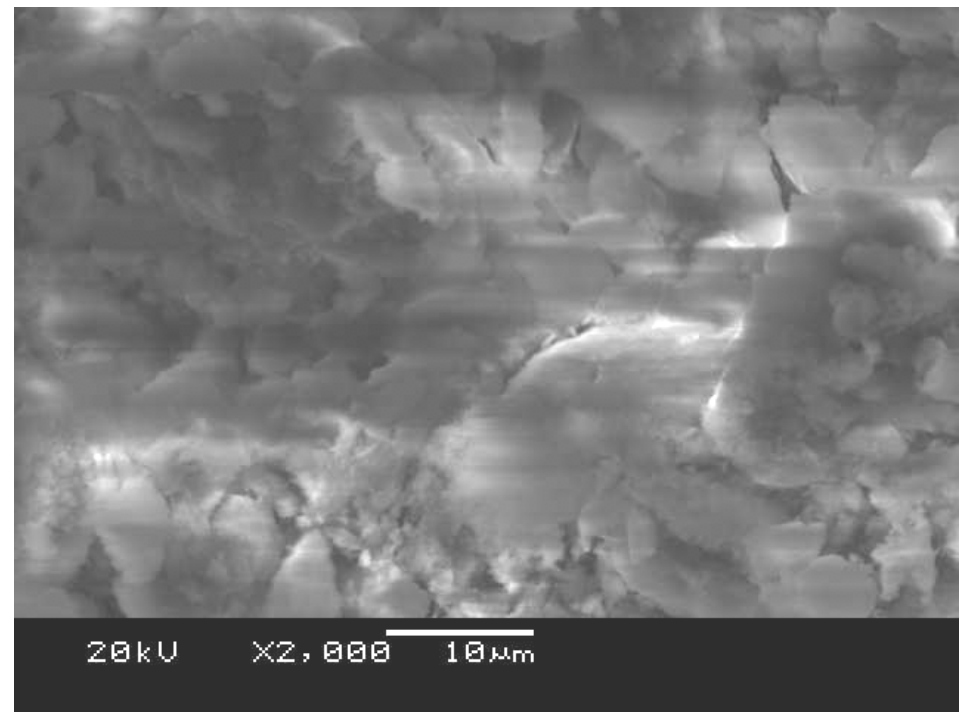

Figure 8. Soil $+1 \%$ Cement $+100 \mathrm{mg} / \mathrm{kg} \mathrm{Cu}$.

Table 2. Physico- chemical properties of Red Soil.

\begin{tabular}{lc}
\hline Property & Red Earth \\
\hline Specific Gravity & 2.64 \\
Liquid Limit (\%) & 38.0 \\
Plastic Limit (\%) & 21.0 \\
Shrinkage Limit (\%) & 18.0 \\
Max Dry Density (KN/m ${ }^{3}$ ) & 16.8 \\
Optimum Moisture Content (\%) & 19.2 \\
Cation Exchange Capacity (Meq/100g) & 18.5 \\
Specific Surface Area $\left(\mathrm{m}^{2} / \mathrm{g}\right)$ & 44.0 \\
Fine Sand \% & 31.8 \\
Silt \% & 30.2 \\
Clay \% & 38.0 \\
Unified Soil Classification Symbol & $\mathrm{CL}$ \\
\hline
\end{tabular}

Table 3. Variation of chromium for different mixtures.

\begin{tabular}{|c|c|c|c|c|c|c|c|c|c|}
\hline \multirow{2}{*}{\multicolumn{4}{|c|}{ Combination of Parameters }} & \multicolumn{6}{|c|}{ Chromium } \\
\hline & & & & \multicolumn{3}{|c|}{ After 7 Days } & \multicolumn{2}{|c|}{ After 28 Days } & \multirow[b]{2}{*}{$\begin{array}{c}\% \\
\text { Leached }\end{array}$} \\
\hline $\begin{array}{l}\text { Sample } \\
\mathrm{N}^{\mathrm{o}}\end{array}$ & $\begin{array}{l}\text { Sample } \\
\text { Code }\end{array}$ & $\begin{array}{l}\text { Load } \\
\text { Ratio in } \\
\mathrm{mg} / \mathrm{kg}\end{array}$ & Sample Composition & $\mathrm{pH}$ & $\begin{array}{l}\text { Conductivity } \\
\text { in } \mathrm{ms}\end{array}$ & $\begin{array}{c}\% \\
\text { Leached }\end{array}$ & $\mathrm{pH}$ & Conductivity & \\
\hline 1 & $\mathrm{C} 1$ & 100 & Red Soil & 5.08 & 0.9 & 47.8 & 5.08 & 0.9 & 47.8 \\
\hline 2 & $\mathrm{C} 2$ & 100 & RedSoil + 3\% lime & 9.38 & 1.3 & 50.1 & 8.33 & 1.7 & 45.6 \\
\hline 3 & $\mathrm{C} 3$ & 100 & Red Soil $+6 \%$ Lime & 11.67 & 1.5 & 45.6 & 8.74 & 1.6 & 42.8 \\
\hline 4 & $\mathrm{C} 4$ & 100 & Red Soil $+1 \%$ Cement & 7.00 & 1.2 & 48.4 & 7.52 & 1.6 & 48.6 \\
\hline 5 & $\mathrm{C} 5$ & 100 & Red Soil $+3 \%$ Cement & 8.50 & 1.3 & 44.5 & 8.22 & 1.7 & 16.2 \\
\hline 6 & C6 & 50 & Red Soil & 6.23 & 0.7 & 44.6 & 6.95 & 0.5 & 48.2 \\
\hline 7 & $\mathrm{C} 7$ & 50 & RedSoil + 3\% lime & 8.65 & 0.8 & 55.6 & 8.41 & 1.1 & 43.4 \\
\hline 8 & $\mathrm{C} 8$ & 50 & Red Soil $+6 \%$ Lime & 11.93 & 1.0 & 28.4 & 9.22 & 1 & 41.4 \\
\hline 9 & $\mathrm{C} 9$ & 50 & Red Soil $+1 \%$ Cement & 7.70 & 0.7 & 38.8 & 7.84 & 1.2 & 50.0 \\
\hline 10 & $\mathrm{C} 10$ & 50 & Red Soil $+3 \%$ Cement & 8.70 & 0.9 & 47.8 & 8.36 & 1.1 & 43.2 \\
\hline
\end{tabular}


MOHAMMED, S. A. S.; NAIK, M.; TANVEERUDDIN, S. Influence of additives on the retention of metal ions in a soil of Bangalore, India. Ambi-Agua, Taubaté, v. 4, n. 1, p. 20-36, 2009. (doi:10.4136/ambi-agua.71)

Table 4. Variation of copper and zinc for different mixtures.

\begin{tabular}{|c|c|c|c|c|c|c|c|c|c|}
\hline \multirow{2}{*}{\multicolumn{4}{|c|}{ Combination of Parameters }} & \multirow{2}{*}{\multicolumn{3}{|c|}{$\begin{array}{c}\text { Copper } \\
\text { After } 28 \text { Days }\end{array}$}} & \multicolumn{3}{|c|}{ Zinc } \\
\hline & & & & & & & & After 28 Day: & \\
\hline $\begin{array}{l}\text { Sample } \\
\mathrm{N}^{\mathrm{o}}\end{array}$ & $\begin{array}{l}\text { Sample } \\
\text { Code }\end{array}$ & $\begin{array}{l}\text { Load } \\
\text { Ratio in } \\
\mathrm{mg} / \mathrm{kg}\end{array}$ & Sample Composition & $\mathrm{pH}$ & $\begin{array}{l}\text { Conductivity } \\
\text { in ms }\end{array}$ & $\begin{array}{c}\% \\
\text { Leached }\end{array}$ & $\mathrm{pH}$ & Conductivity & $\begin{array}{c}\% \\
\text { Leached }\end{array}$ \\
\hline 1 & $\mathrm{C} 1$ & 100 & Red Soil & 4.86 & 1.2 & 18.5 & 5.08 & 1.2 & 43.2 \\
\hline 2 & $\mathrm{C} 2$ & 100 & RedSoil + 3\% lime & 7.34 & 1.4 & 12.6 & 6.74 & 1.1 & 13.3 \\
\hline 3 & $\mathrm{C} 3$ & 100 & Red Soil + 6\% Lime & 8.12 & 1.9 & 6.5 & 7.72 & 1 & 10.6 \\
\hline 4 & $\mathrm{C} 4$ & 100 & Red Soil $+1 \%$ Cement & 6.64 & 1.5 & 12.5 & 6.54 & 1.4 & 16.7 \\
\hline 5 & $\mathrm{C} 5$ & 100 & Red Soil $+3 \%$ Cement & 6.91 & 1.4 & 12.1 & 7.42 & 1.5 & 16.3 \\
\hline 6 & C6 & 50 & Red Soil & 6.52 & 0.9 & 17.8 & 6.20 & 0.9 & 34.1 \\
\hline 7 & $\mathrm{C} 7$ & 50 & RedSoil + 3\% lime & 7.74 & 1.0 & 10.8 & 9.95 & 0.9 & 12.6 \\
\hline 8 & $\mathrm{C} 8$ & 50 & Red Soil + 6\% Lime & 8.10 & 2.1 & 8.9 & 10.74 & 2.2 & 12.6 \\
\hline 9 & C9 & 50 & Red Soil $+1 \%$ Cement & 6.93 & 0.9 & 7.6 & 7.83 & 1.4 & 13.1 \\
\hline 10 & $\mathrm{C} 10$ & 50 & Red Soil $+3 \%$ Cement & 7.27 & 1.2 & 10.1 & 10.63 & 1.8 & 12.3 \\
\hline
\end{tabular}

Table 5. Variation of potassium for different mixtures.

\begin{tabular}{|c|c|c|c|c|c|c|c|c|c|}
\hline \multirow{2}{*}{\multicolumn{4}{|c|}{ Combination of Parameters }} & \multicolumn{6}{|c|}{ Potassium } \\
\hline & & & & \multicolumn{3}{|c|}{ After 7 Days } & \multicolumn{3}{|c|}{ After 28 Days } \\
\hline $\begin{array}{l}\text { Sample } \\
\mathrm{N}^{\mathrm{o}}\end{array}$ & $\begin{array}{l}\text { Sample } \\
\text { Code }\end{array}$ & $\begin{array}{l}\text { Load } \\
\text { Ratio in } \\
\mathrm{mg} / \mathrm{kg}\end{array}$ & Sample Composition & $\mathrm{pH}$ & $\begin{array}{l}\text { Conductivity } \\
\text { in } \mathrm{ms}\end{array}$ & $\begin{array}{c}\% \\
\text { Leached }\end{array}$ & $\mathrm{pH}$ & Conductivity & $\begin{array}{c}\% \\
\text { Leached }\end{array}$ \\
\hline 1 & $\mathrm{C} 1$ & 100 & Red Soil & 7.20 & 1.4 & 52.8 & 7.20 & 1.4 & 46.0 \\
\hline 2 & $\mathrm{C} 2$ & 100 & RedSoil + 3\% lime & 11.03 & 1.4 & 62.0 & 7.84 & 1.2 & 18.4 \\
\hline 3 & $\mathrm{C} 3$ & 100 & Red Soil $+6 \%$ Lime & 13.03 & 2.0 & 55.6 & 7.90 & 1.2 & 18.4 \\
\hline 4 & $\mathrm{C} 4$ & 100 & Red Soil $+1 \%$ Cement & 9.33 & 0.9 & 32.0 & 7.82 & 1.3 & 20.0 \\
\hline 5 & C5 & 100 & Red Soil $+3 \%$ Cement & 10.06 & 1.3 & 56.4 & 8.30 & 1.2 & 16.8 \\
\hline 6 & C6 & 50 & Red Soil & 8.40 & 0.6 & 61.2 & 6.38 & 0.8 & 20.8 \\
\hline 7 & $\mathrm{C} 7$ & 50 & RedSoil $+3 \%$ lime & 11.21 & 0.7 & 24.0 & 7.45 & 0.8 & 14.4 \\
\hline 8 & $\mathrm{C} 8$ & 50 & Red Soil $+6 \%$ Lime & 12.70 & 1.3 & 35.2 & 8.45 & 0.7 & 14.4 \\
\hline 9 & $\mathrm{C} 9$ & 50 & Red Soil $+1 \%$ Cement & 9.71 & 0.9 & 64.0 & 7.70 & 0.8 & 25.6 \\
\hline 10 & $\mathrm{C} 10$ & 50 & Red Soil $+3 \%$ Cement & 11.30 & 0.6 & 32.0 & 8.50 & 0.8 & 20.8 \\
\hline
\end{tabular}

Table 6. Variation of Sodium for different mixtures.

\begin{tabular}{|c|c|c|c|c|c|c|c|c|c|}
\hline \multirow{2}{*}{\multicolumn{4}{|c|}{ Combination of Parameters }} & \multicolumn{6}{|c|}{ Sodium } \\
\hline & & & & \multicolumn{3}{|c|}{ After 7 Days } & \multicolumn{3}{|c|}{ After 28 Days } \\
\hline $\begin{array}{c}\text { Sample } \\
\mathrm{N}^{\mathrm{o}}\end{array}$ & $\begin{array}{l}\text { Sample } \\
\text { Code }\end{array}$ & $\begin{array}{l}\text { Load } \\
\text { Ratio in } \\
\mathrm{mg} / \mathrm{kg}\end{array}$ & Sample Composition & $\mathrm{pH}$ & Conductivity & $\begin{array}{c}\% \\
\text { Leached }\end{array}$ & $\mathrm{pH}$ & Conductivity & $\begin{array}{c}\% \\
\text { Leached }\end{array}$ \\
\hline 1 & $\mathrm{C} 1$ & 100 & Red Soil & 7.83 & 1.8 & 46.0 & 7.83 & 1.8 & 52.0 \\
\hline 2 & $\mathrm{C} 2$ & 100 & RedSoil $+3 \%$ lime & 10.89 & 1.9 & 18.4 & 8.4 & 1.8 & 21.3 \\
\hline 3 & $\mathrm{C} 3$ & 100 & Red Soil $+6 \%$ Lime & 12.83 & 2.8 & 20.0 & 8.32 & 1.7 & 30.4 \\
\hline 4 & $\mathrm{C} 4$ & 100 & Red Soil $+1 \%$ Cement & 8.72 & 1.7 & 18.4 & 8.96 & 1.9 & 25.6 \\
\hline 5 & $\mathrm{C} 5$ & 100 & Red Soil $+3 \%$ Cement & 10.98 & 1.8 & 16.8 & 8.9 & 1.8 & 19.2 \\
\hline 6 & C6 & 50 & Red Soil & 7.75 & 0.7 & 20.0 & 8.5 & 1.2 & 28.8 \\
\hline 7 & $\mathrm{C} 7$ & 50 & RedSoil + 3\% lime & 10.67 & 1.2 & 19.2 & 8.36 & 1.0 & 19.2 \\
\hline 8 & $\mathrm{C} 8$ & 50 & Red Soil $+6 \%$ Lime & 12.8 & 1.8 & 20.0 & 8.54 & 1.0 & 19.2 \\
\hline 9 & C9 & 50 & Red Soil $+1 \%$ Cement & 8.63 & 0.9 & 20.0 & 8.53 & 1.2 & 30.4 \\
\hline 10 & $\mathrm{C} 10$ & 50 & Red Soil $+3 \%$ Cement & 10.47 & 1.3 & 19.2 & 9.12 & 1.1 & 27.2 \\
\hline
\end{tabular}




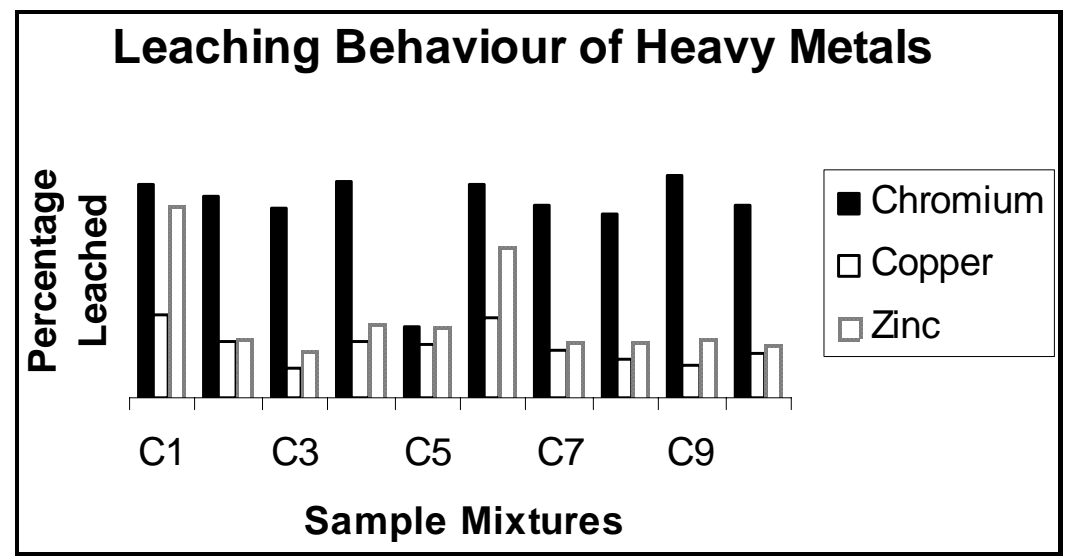

Figure 9. Percentage leaching of heavy metals.

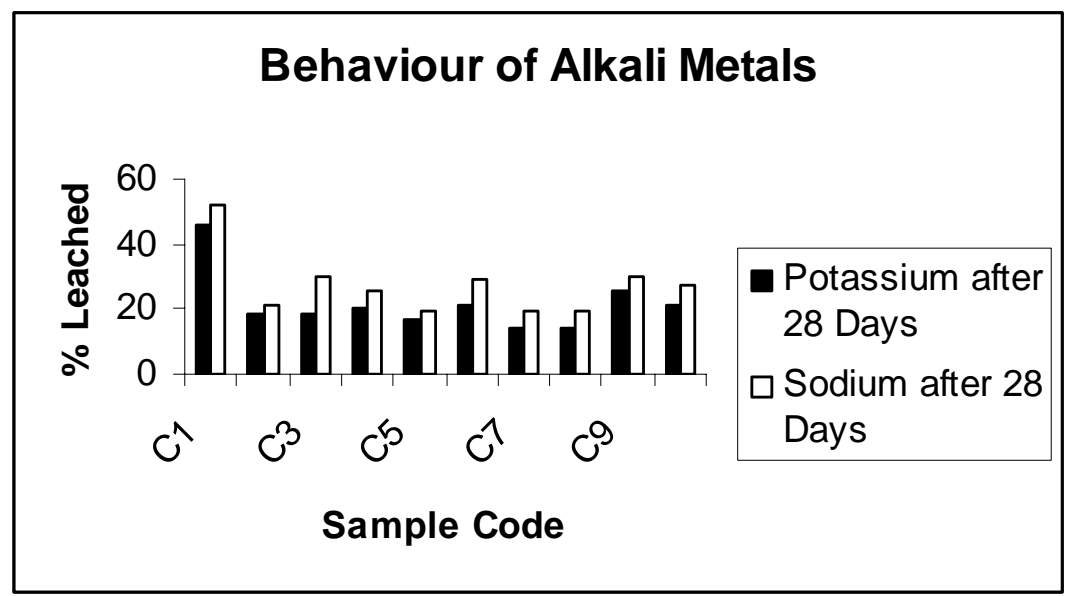

Figure 10. Percentage leaching of potassium and sodium.

\section{CONCLUSIONS}

From the present study the following general conclusions can be drawn.

Enhanced retention capacity for contaminants has been obtained with Red Soil of Bangalore with additives like cement and lime. Copper is sorbed immediately due to formation of organic ligands and complexes, specific adsorption of $\mathrm{Cu}$ onto $\mathrm{CaCO}_{3}$ surfaces has taken place. Zinc has been sorbed mostly due to precipitation of zinc into zinc hydroxide. Chromium is the least sorbed and is subjected to nonspecific adsorption. The sorption sequence for the heavy metals considered are $\mathrm{Cu}>\mathrm{Zn}>\mathrm{Cr}$.

Maximum sorption of copper and zinc was observed at relatively higher $\mathrm{pH}$ due to various geochemical reactions. Potassium and sodium are mostly sorbed by cation exchange and formation of diffuse double layer. Potassium is subjected to specific adsorption due to lower hydrated radius of its ions and sodium is subjected to non specific adsorption, it is dispersive in nature. The sorption sequence is $\mathrm{K}>\mathrm{Na}$.

SEM observations reveal at higher size range regular porous like large particles were detected from virgin soil. In the regular porous sponge like particles, crystals seem to be of alumino silicate which is widely used as an adsorbent for removal of metals, indicating possibility of using Red Soil as an adsorbent for removing metal ions. SEM observations of samples spiked with sodium, potassium, zinc and copper show aggregation and formation of homogenous mass from regular sponge like particles of virgin soil, which demonstrate that sorption has taken place. 
Energy Dispersive Spectroscope (EDS) analysis indicates the presence of elements like $\mathrm{Si}, \mathrm{Al}, \mathrm{Ca}, \mathrm{Ti}, \mathrm{Fe}, \mathrm{k}, \mathrm{Na}$. This is in accordance with the conductivity data obtained experimentally.

\section{ACKNOWLEDGEMENTS}

Sincere thanks to the encouragement of Honourable Administrator Mr. Abdul Hameed S. A., Respected Principal Dr. Chaitanya Kumar M. V., Head of Engineering Chemistry, Prof. Sanaulla P. F. of HKBK College of Engineering, Bangalore 5600 45. Appreciation is expressed to Mr. M. N. Zulfiqar Ahmed, Senior Lecturer Dept. of Eng. Chemistry HKBKCE for helping in setting up the experiments.

We are highly indebted for the scholastic help rendered by Prof. Dr. P. V. Sivapullaiah, Prof of Civil Engineering and Mr. Mughal Arif Ali Baig, Research Scholar, Indian Institute of Science (IISc), Bangalore 560012.

\section{REFERENCES}

ALI BAIG, AARIF; SIVAPULLAIAH, P. V.; Heavy metal leachability of low lime flyashes., In: Indian Geotechnical Conference - 2008: Advances in Geotechnical Enginnering GEOAGE Bangalore .Proceedings Vol II, p. 470 - 473, 2008

ASTM INTERNATIONAL - AMERICAN STANDARD TESTING METHOD . D3987 - 85 (reapproved 2004), Standard test mMethod for shake extraction of solid waste with water. West Conshohocken: ASTMUSA, 2004. p. $1-5$.

BAR-YOSEF, P. H. Dependent zinc adsorption of soils. Soil Sci.Am Journal, v. 43, p. 1095 - 1099, 1979.

GROVE, J. H.; ELLIS, B. G. Extractable chromium as related to soil $\mathrm{pH}$ and applied chromium. Soil Sci. Soc. Am. J., v. 44, p. 238-242, 1980.

JEFFERY, G. H.; BASSETT, S.; MENDHAM, J. Vogel's text book of quantitative chemical analysis. 5.ed. New York: John Wiley \& Sons, 1997. p. 953.

JEOL ANALYTICAL SUPPLIERS. SEM Tutorials 2008. Available: $<$ http://www.jeol.com>. Access: January 2009.

KANTHA, H. LAKSHMI; SIVAPULLAIAH, P. V. Clay minerals as liner material for waste containment facilities. 2000. Thesis (Doctoral degree in Civil Engineering) Indian Institute of Science, (IISc), Bangalore, 2000.

KANTHA, H. LAKSHMI; SIVAPULLAIAH, P. V.; MADHU, KIRAN. Geotechnical properties of stabilised Indian red earth. Geotechnical and Geological Engineering, v. 21, p. 399-413, 2003.

KURDI, F.; DONER, H. E. Zinc and copper sorption an interaction in soils. Soil Sci. Soc. Am. J., v. 47, p. 873-876, 1983.

LO, H. M.; LIN, K. C. Solubility of heavy metals added to MSW. Journal of Hazardous Materials, v. 161, p. $294-299,2009$.

MCBRIDE, M. B.; BOULDIN, D. R. Long-term reactions of copper(II) in a contaminated calcareous soil. Soil Sci. Soc. Am. J., v. 48, p. 56-59, 1984. 
MC LEAN, JOAN E.; BERT, E. Behaviour of metals in soils. Environmental Protection Agency Report nº 540 S- 92-018. Ada: EPA, 1992.

MOHAMMED, S. A. S.; NAIK, MAYA. Innovative materials as liners for waste containment facilities., In: TECHNOMILLENIUM 2006 - INTERNATIONAL TECHNICAL SYMPOSIUM, Aurangabad, 2006. Proceedings p. 170 - 176, 2006.

NAIK, MAYA; MOHAMMED, S. A. S. Influence of additives on the retention of heavy metal ions in local Red Soil of Bangalore City, RETBE 08. In: INTERNATIONAL CONFERENCE, 7., 2008. Procedings... Egypt: Alexandria University, 2008. 1 CDROM.

NAIK, MAYA; SIVAPULLAIAH, P. V. Influence of diffusion coefficient and retardation factor in contaminant transport through soil liners. 2003. Thesis (Doctoral degree in Civil Engineering) - Indian Institute of Science, Bangalore, 2003.

RAJASEKHAR, C.; SRIDHARAN, A.; PANDIAN, N. S. Effect of lime on the heavy metals ions retention characteristics of Fly Ash. In: SYMPOSIUM ON NATURAL HAZARDS AND ENVIRONMENTAL GEOTECHNIQUES, Bangkok, 1995. Proceedings p. 1-9, 1995.

TANIT, C.; SURAPON, A.; NANTHANIT, C. Potential use of lateritic and marine clay soils as landfill liners to retain heavy metals. Journal of Waste Management, v. 29, p. 117 $-127,2009$.

UNIVERSITY OF NEW SOUTH WALES. Terra GIS Soil, 2007. Available: $<$ http://www.terraGIS Soil.org > . Access June 18, 2008.

YOUNG, SOOK SHIM; YOUNG, KEUM KIM. The adsorption characteristics of heavy metals by various particle sizes of MSWI bottom ash. Journal of Waste Management, v. 23, p. $851-857,2003$. 